\title{
Protein Engineering for Improved Pharmacologic Characteristics of Established Monoclonal Antibody-Based Therapeutics
}

\author{
Bernd Meibohm
}

Published online: 12 September 2014

(C) Springer International Publishing Switzerland 2014

Since the widespread clinical introduction of chimeric, humanized and human monoclonal antibodies more than 15 years ago, monoclonal antibody based therapeutics have conquered substantial ground as major players and in some indications even cornerstones in the pharmacotherapeutic management of a variety of serious medical conditions [1].

While monoclonal antibodies with novel targets and antibody based derivatives such as antibody-drug conjugates, antibody fragments, antibody-based fusion proteins, bispecific antibodies, nanobodies and similar constructs have received much attention in recent years [2, 3], refining and optimizing the protein structure and subsequently pharmacologic properties of established, clinically used monoclonal antibodies is gaining increasing interest. While this effort is likely partly driven by patent expirations and the growing momentum for establishing a viable and effective biosimilar market for monoclonal antibodies in many nations [4], it also opens a pathway to apply recent advances in protein engineering and manufacturing to create derivatives that form a new, improved generation of established therapeutic proteins.

The article by Othman et al. [5] in this issue of Clinical Pharmacokinetics describes a population pharmacokinetic analysis for one such next-generation monoclonal antibody, daclizumab high yield process (HYP) as improved version of daclizumab $\left(\right.$ Zenapax $\left.^{\circledR}\right)$. While daclizumab is approved in the US for prophylaxis of acute organ rejection in patients receiving renal transplants, daclizumab HYP seeks to gain approval for a new indication, relapsing-remitting multiple

\section{B. Meibohm ( $\square)$}

College of Pharmacy, University of Tennessee Health Science Center, 881 Madison Avenue, Rm. 444, Memphis, TN 38163, USA

e-mail: bmeibohm@uthsc.edu sclerosis, competing with a number of other established therapeutic proteins including interferon beta- $1 \mathrm{a}$, interferon beta- $1 \mathrm{~b}$, natalizumab, and the polypeptide glatiramer acetate. Compared to daclizumab, daclizumab HYP is characterized by improved production and purification processes, which result in distinct differences in the heavy chain $\mathrm{N}$-terminal sequences as well as the glycan structure. Compared to daclizumab, the daclizumab HYP glycan pattern is substantially less heterogeneous, with a homogenous $\mathrm{N}$-linked glycosylation profile and a lack of nonfucosilated forms. As afucosulation has been described as a major driver for antibody-dependent cellular cytotoxity [6], lack of this glycan structure in daclizumab HYP minimizes any antibody dependent cellular cytotoxicity (ADCC)-related effector function which has been confirmed experimentally [7]. Similarly, the modified antibody structure may affect the immunogenicity and clearance of daclizumab HYP.

The population pharmacokinetic analysis by Othman et al. [5] seems to confirm differences in the pharmacokinetic behavior between daclizumab and daclizumab HYP. Although previous public reports on daclizumab pharmacokinetics have been limited, the presented results suggest that daclizumab HYP has an approximately $30 \%$ reduced systemic clearance compared to daclizumab. This observation would be consistent with a reduction in ADCC and Fc-receptor-mediated elimination. Future investigations may reveal additional improved pharmacologic properties of daclizumab HYP compared to daclizumab, for example with regard to immunogenicity or pharmacologic efficacy.

Overall, this example shows how slight structural modifications by protein engineering can be utilized to optimize the pharmacologic profile of established monoclonal antibody-based therapeutics to produce the next generation of therapeutic proteins with an improved therapeutic profile. 


\section{References}

1. Dirks NL, Meibohm B. Population pharmacokinetics of therapeutic monoclonal antibodies. Clin Pharmacokinet. 2010;49(10):633-59.

2. Kontermann RE. Dual targeting strategies with bispecific antibodies. MAbs. 2012;4(2):182-97.

3. Wu AM, Senter PD. Arming antibodies: prospects and challenges for immunoconjugates. Nat Biotechnol. 2005;23(9):1137-46.

4. Feagan BG, Choquette D, Ghosh S, Gladman DD, Ho V, Meibohm $\mathrm{B}$, et al. The challenge of indication extrapolation for infliximab biosimilars. Biologicals. 2014;42(4):177-83.
5. Othman AA, Tran JQ, Tang MT, Dutta S. Population pharmacokinetics of daclizumab high-yield process in healthy volunteers: integrated analysis of intravenous and subcutaneous, single- and multiple-dose administration. Clin Pharmacokinet. 2014. doi:10. 1007/s40262-014-0159-9.

6. Yamane-Ohnuki N, Satoh M. Production of therapeutic antibodies with controlled fucosylation. MAbs. 2009;1(3):230-6.

7. Hartman TE, Sauer PW, Burky JE, Wesson MC, Huang PY, Robinson TJ, et al., inventors. DAC HYP compositions and methods. US patent US 2012/0301429 A1. 29 Nov 2012. 